\title{
NO RIGHT WITHOUT A REMEDY: FOUNDATIONS OF INVESTOR-STATE ARBITRATION
}

\author{
SERGIO PUIG* \\ "obligations that exist, but cannot be enforced, are ghosts... \\ elusive to the grasp." \\ —Justice Oliver Wendell Holmes, Jr.
}

\begin{abstract}
This Article explores a fundamental aspect of modern international investment law: its remedy to enforce a breach. I argue that investorstate arbitration is subject to different conceptualizations that may animate the way in which adjudicators understand what type of right is conferred to investors when granted the invocation of responsibility against a host state. I explore the consequences of the three distinct conceptualizations (i.e., direct right, beneficiary right, or agency) by reference to the current debate regarding to whom countermeasures are opposable under international law. I show how the three dimensions imply that the construction of substantive law entails important assumptions about the procedures that will apply when that substantive law is ultimately enforced. In this sense, the Article evidences some of the methodological limitations of the 'procedural-substantive' distinction often encountered in international law analysis.
\end{abstract}

* Associate Professor, James E. Rogers College of Law, University of Arizona (July 2014); formerly Counsel at ICSID and Teaching Fellow at Duke and Stanford Law Schools. I would like to thank Negar Katirai, Joost Pauwelyn, and Lucy Seyfarth. I am obliged to disclose that between 2007 and 2010 I worked as counsel in the World Bank's legal vice-presidency and ICSID's secretariat. Also, between 2004 and 2006 I acted as a counsel for Corn Products International Inc., the claimant in one case discussed in this chapter. An abridged version of this Article will also appear in THE FOUNDATIONS OF INTERNATIONAL INVESTMENT LAW: Bringing Theory Into Practice, Z. Douglas, J. Pauwelyn, And J. E. Vinuales, OXFORD UNIVERSITY PRESS, OUP (2014). All errors are mine. 


\section{TABLE OF CONTENTS}

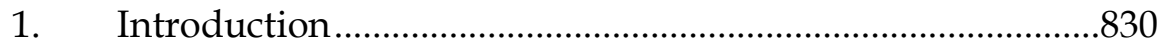

2. Origins: A Procedural Functionalist Enterprise ....................832

3. Function of Remedy: Three Different Goals ...........................834

3.1. Background ..........................................................................835

3.2. Procedural Justice: Guarantee of Bargaining Power...

3.3. Corrective Justice: Compartmentalization of International Economic Conflicts.

3.4. Deterrence: Prevention of Opportunistic Behavior of

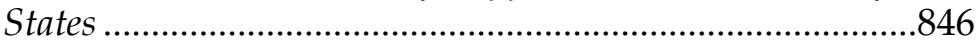

4. Nature of Right: Functional Relationship .............................848

4.1. Background. 848

4.2. Third-Party Rights: Access to Justice and Dispute Settlement.

4.3. Direct Rights: De-Politicization and Compensation

4.4. Delegated Rights: Risk Assessment and Conflict Prevention

5. Conclusion 860

\section{INTRODUCTION}

In 1803, Chief Justice Marshall observed that a government cannot be called a "government of laws, and not of men . . . if the laws furnish no remedy for the violation of a vested legal right." 1 Justice Marshall's celebrated quote is more than a modest reminder that in any given legal system there is no right without a remedy. It is a restatement that when governments themselves violate legal rights, it is especially important to furnish a remedy.

To be sure, legal scholars agree that providing remedies to the victims of violations of rights after the fact-whether this law is domestic or international-is an imperfect solution at best. However, the disagreement seems to emerge generally once lawyers and legal scholars attempt to define what is the chief goal of a particular legal remedy. For instance, a remedy plausibly provides reparation in certain instances or the opportunity to ventilate grievances in other situations. Ideally, backward-looking remedies can deter future violations. In theory, if government officials or agencies know that they will be held to account, they will be less likely to commit violations in the first place. More

1 Marbury v. Madison, 5 U.S. 137, 163 (1803). 
broadly, remedies perform an important expressive function: they drive home the idea that the law takes violations seriously.

As investor-state arbitration becomes the dominant remedy to enforce international investment obligations, it is important to ask the following questions: What is the primary purpose of investorstate arbitration? And, how the different functional conceptualizations of investor-state arbitration would-in practice-interact with the rights conferred under international law? The two fundamental questions may be at the crux of one of the main debates of the field, as can be discerned from recent cases before the International Centre for Settlement of Investment Disputes (ICSID).

In this essay, I analyze an external face and fundamental part of international investment law: its remedy to enforce a breach. I argue that the remedy is subject to different conceptualizations that may affect the way in which adjudicators understand what type of right (i.e., direct rights, beneficiary rights, or agency) is conferred to investors when granted the direct invocation of responsibility against a host state. I do so by reference to the debate around the operation of the circumstances precluding wrongfulness for the breach of an investment treaty by characterizing a conduct as a countermeasure in response to an anterior breach by a home state. Or-in more simple terms - the debate regarding to whom international countermeasure are opposable. Using this debate, I show that the different justifications relied upon to promote investor-state arbitration as the main remedy of bilateral investment treaties (BITs) allow at least three different understandings of that question and, by implication, different relational dimensions of remedy. These different conceptualizations emphasize investor-state arbitration as enabling (primarily) one of the following functions of legal remedies: (a) procedural justice; (b) corrective justice; or (c) deterrence.

Before proceeding, a cautionary note is in order: the analysis in this essay provides an opportunity to examine whether and how the invocation of responsibility by a non-state actor against a host state can be conceptualized in different ways and some of the consequences thereof. Whether the interpretation of the rights should be necessarily determined by such conceptualization, as a starting point, is a different question. This is ultimately a matter of 
treaty interpretation. ${ }^{2}$ However, for the purpose of this Article, and in no way dismissing the issues noted above, a lack of interpretative guidance in the relevant treaty will be taken for granted. Not only is the interpretative guidance of BITs on this issue generally unclear, but it is in these situations that adjudicators may reveal their assumptions of a remedy. As I hope to illustrate, this is not to say that the different conceptual foundations do not affect-consciously or unconsciously-the interpretative function performed by arbitrators.

The Article begins with a brief discussion of the intellectual justifications and legal ideas behind investor-state arbitration. It continues with a main analysis that unpacks three different justifications for allowing the invocation of responsibility to a nonstate actor directly against a state before an arbitral forum. The Article concludes by surveying the debate around the circumstances precluding wrongfulness showing how, at the crux of it, there is a fundamental disagreement on the main goal of investor-state arbitration and explaining how this insight can be applied to other, similar debates. By engaging with such debates from this perspective-more broadly -I seek to illustrate why the procedural dimension of international investment law (remedy) cannot be completely detached from its substantive connotations (rights).

\section{ORIGINS: A PROCEDURAL FUNCTIONALIST ENTERPRISE}

The end of World War II, the dissolution of empires, and the decolonization process brought a stronger need for a legal system of protection of foreign direct investment (FDI). This need arose at a time when a dialogue between two distinct legal conceptions was heavily influencing international law. ${ }^{3}$ On the one hand, legal positivism-whose adherents included primarily European civil law scholars - argued for the separation of law and morality and

2 See Martins Paparinskis, Investment Treaty Arbitration and the (New) Law of State Responsibility, 24 EUR. J. INT'L L. 617, 626 (2013) (arguing that the choice between direct rights and agency approaches is a matter of treaty interpretation).

3 See Bruce L. Benson, The Spontaneous Evolution of Commercial Law, 55 S. ECON. J. 644, 645-47 (1989) (distinguishing between legal positivists from natural law theorists in the context of understanding the development of commercial law). For a more complete discussion on the background of ICSID, please refer to Sergio Puig, Recasting ICSID'S Legitimacy Debate: Towards A Goal-Based Empirical Agenda, 36 FORDHAM INT'L L.J. 465 (2013). 
considered the law as being posited by lawmakers. ${ }^{4}$ On the other hand, natural law theory as presented in a more secular form adopted a different view. Natural law theorists, developed largely out of the common law tradition (which historically resisted the separation of morality and law), championed legal processes and institutional order as essential components of a market-based society. ${ }^{5}$ Under both traditions, the law serves an important coordinative function by providing a framework against which individuals and organizations might orient actions as well as rationally evaluate interactions with others and plan ahead. ${ }^{6}$

These two conceptions of law (legal positivism and secularized naturalism) dominated Western legal jurisprudence in the 1960's. Inspired by H. L. A. Hart and the legal philosophy of Lon L. Fuller, and profoundly located within classical liberalism's traditional emphasis of liberty and freedom, these conceptions may have influenced the creation of some important international law initiatives of that time. ${ }^{7}$ Among other influences, legal forms experienced a process of assimilation of instrumentalism and formalism. In its final analysis it meant that international legal orders were not only the way to subject human conduct to the governance of legitimate rules, but also to limit evil regimes from implementing substantially unjust laws that curtail liberties,

4 See generally H. L. A. Hart, Positivism and the Separation of Law and Morals, 71 HARV. L. REV. 593, 599 (1958) (defending legal positivism from critics); Stanley L. Paulson, Four Phases in Hans Kelsen's Legal Theory? Reflections on a Periodization, 18 OxFORD J. LEGAL STUD. 153 (1998) (identifying key claims and evolution of legal positivism).

5 See Lon L. Fuller, The Morality of Law 145 (rev. ed. 1969) (“[L]aw [is] ... a purposeful enterprise, dependent for its success on the energy, insight, intelligence, and conscientiousness of those who conduct it, and fated, because of this dependence, to fall always somewhat short of a full attainment of its goals."); Lon L. Fuller, Reason and Fiat in Case Law, 59 HARV. L. ReV. 376, 379 (1946) (suggesting that natural law refers to the belief that there are external criteria "found in the conditions required for successful group living" against which a judge can evaluate his decision).

6 In secularized individualistic societies, certainty, objectivity and neutrality tend to be important constitutive values. See Jeremy Waldron, The Concept and the Rule of Law, 43 GA. L. REV. 1, 48 (2008) ("Law in the first sense requires the existence of certain general norms that serve as a basis of orientation for people's behavior, as well as a basis for decision by the courts.").

7 See David Kennedy, Challenging Expert Rule: The Politics of Global Governance, 27 SYDNEY L. REV. 5, 19-20 (2005) ("Experts argue for their preferred policy or doctrinal choice by reference to broader theories, methods and political commitments which they associate with the doctrine or policy they prefer. For lawyers, these can be theories of law - positivism, naturalism, sociology ...."). 
including economic ones. Individual rights represented a form of empowerment to liberate the individual from the state's subjugation, as well as to enable direct enforcement of such substantive ends of the law. ${ }^{8}$ For the development of the international law applicable to investors abroad, the result of this process of assimilation was the revival of a procedural functionalist enterprise with, among others, the following features:

(1) a predominant concern for individual rights and protection of property;

(2) rules enforced by the victims backed by treaties or reciprocal agreements;

(3) standard adjudicative procedures established to avoid the escalation of violence;

(4) offenses treated as torts punishable by economic reparation;

(5) strong incentives for the culprit to yield to the prescribed decision due to threat of international ostracism; and

(6) legal change via an evolutionary process of developing interpretations, customs and norms. ${ }^{9}$

\section{FUNCTION OF REMEDY: THREE DIFFERENT GOALS}

Investor-state arbitration is the poster-child of international legalization, a phenomenon salient in modern international economic relations. ${ }^{10}$ The International Centre for Settlement of Investment Disputes ("ICSID" or the "Centre"), one of the five organizations of the World Bank ("WB"), can be credited with the

8 This rhetoric not only makes it hard to assess questions of distribution among favored and less favored rights holders. See MAX WEBER, LAW IN ECONOMY AND SOCIETY 188 (Max Rheinstein ed., Edward Shils \& Max Rheinstein trans., 1967) ("The development of legally regulated relationships . . . is usually regarded as signifying a decrease of constraint and an increase of individual freedom.").

9 For a similar argument, see BRUCE L. BENSON, THE ENTERPRISE OF LAW: Justice Without THE STATE 21 (1990).

10 For an analysis of the different perspectives on legalization and the theoretical puzzles that legalization poses for international institutions, see Judith Goldstein et al., Introduction: Legalization and World Politics, 54 INT'L ORG. 385, 386 (2000) ("These actions, taken in the course of a single year, were representative of a longer term trend: some international institutions are becoming increasingly legalized."). 
rapid expansion and popularity of investor-state arbitration as primary remedy to address conflicts over investments abroad.11

The signing of the ICSID Convention and the creation of the Centre not only gave origin to an international organization specializing in international investment disputes settlement (i.e., ICSID), but it also facilitated the expansion and popularization of a system of protections for foreign investors based on a remedy for damages directly enforceable by individuals or corporations against states (i.e., private right of action). More importantly, the Convention and the Centre served to promote a particular understanding of the role of foreign direct investment ("FDI") in national economic development, to stabilize a vision of economic cooperation, and to advance-especially, after the Soviet collapse - an idea of an international "rule of law" via BITs. ${ }^{12}$

Without being exhaustive, what follows is a brief recounting of some legalization efforts prior to the signing of the ICSID Convention. These efforts contextualize the three justificatory functions of investor-state arbitration as remedy of choice for the enforcement of international investment agreements.

\subsection{Background}

Prior to the 1960's, international investment dispute settlement looked different and was heavily dependent on traditionally mercantilist relationships. ${ }^{13}$ In other words, in contrast with the current "hybrid," decentralized, and increasingly privatized system, international adjudication was built around inter-state relations. ${ }^{14}$

11 Convention on the Settlement of Investment Disputes between States and Nationals of Other States, opened for signature Mar. 18, 1965, 17 U.S.T. 1270, 575 U.N.T.S. 159 [hereinafter ICSID Convention]. The five organizations of the World Bank ("WB") group are: International Finance Corporation ("IFC"), Multilateral Investment Guarantee Agency ("MIGA"), International Bank for Reconstruction and Development ("IBRD"), International Development Association ("IDA"), and International Centre for Settlement of Investment Disputes ("ICSID").

12 See generally Alvaro Santos, The World Bank's Uses of the "Rule of Law" Promise in Economic Development, in THE NEW LAW AND ECONOMIC DEVELOPMENT: A CRItical APPRAISAL 253, 253-83 (David M. Trubek \& Alvaro Santos eds., 2006).

13 Kenneth J. Vandevelde, A Brief History of International Investment Agreements, 12 U.C. DAVIS J. INT'L L. \& POL'Y 157, 173-75 (2005) (noting that one innovation of ICSID Convention was the possibility of investor-state arbitration).

14 See generally Zachary Douglas, The Hybrid Foundations of Investment Treaty Arbitration, 74 BRIT. Y.B. INT'L L. 151, 184-289 (2003) (discussing the choice of law 
Conflicts over the treatment of property of nationals abroad have existed - at least-since the growing strength of a bourgeois merchant class in England and the Netherlands succeeded in the chartering of trade companies for overseas expansion. This victory gave rise to a mercantilist expansion in the early 17 th century. ${ }^{15}$ Conflicts then were resolved by some of the methods relied upon today (e.g., negotiation, mediation, conciliation, arbitration, and adjudication) as well as some other methods that are no longer permissible under international law (e.g., armed interventions for the collection of debts or privateers authorized by a government by letters of marquee). ${ }^{16}$

Foreign investments were put to international adjudication - at least-as early as the end of the eighteenth century, when mixed arbitral commissions under Jay's Treaty of 1794 addressed the settlement of debts to British creditors. ${ }^{17}$ Since then, Mixed Claims Commissions and ad hoc Tribunals (e.g., France-Venezuela, IranUnited States, United States-Germany, Mexico-United States, or Iran-United States) developed as an alternative to a centralized international judicial system. These commissions expanded until the Friendship, Commerce, and Navigation Treaties ("FCNs") started providing for state-to-state dispute resolution by the International Court of Justice after the World-War II.18 Provisions

problems related to jurisdictional conflicts between tribunals established by treaties, and those constituted pursuant contract).

15 See Anoush Khoshkish, International Law of Investment: An Overview, GLOBAL POLITICAL ECON. (2012), http://www.globalpoliticaleconomy.com/ art_intlaw.html ("[T]he British East India Company, 1600; the Dutch East India Company, 1602; the United East India Company (Dutch), 1602; the Dutch West India Company, 1621; and a number of others which had varying degrees of success depending on the territories they were targeting.").

16 Convention Respecting the Limitation of the Employment of Force for the Recovery of Contract Debts art. 1, Oct. 18, 1907, 36 Stat. 2241, 1 Bevans 607. This was the first effort to limit the collection of debt by forcible means. While the early twentieth century prohibition on the use of force to collect debts in the Hague Conventions was partial, it represented an important step towards the prohibition, not without caveats, of the use of force under international law. See U.N. Charter art. 2, para. 4 ("All Members shall refrain in their international relations from the threat or use of force against the territorial integrity or political independence of any state, or in any other manner inconsistent with the Purposes of the United Nations.").

17 Barton Legum, Federalism, NAFTA Chapter Eleven and the Jay Treaty of 1794, 95 AM. SOC'Y INT'L L. PROC. 202, 203-05 (2001).

18 William S. Dodge, Investor-State Dispute Settlement Between Developed Countries: Reflections on the Australia-United States Free Trade Agreement, 39 VAND. J. 
in modern BITs concerning dispute settlement as well as national treatment, most-favored-nation treatment, the minimum standard of treatment, and expropriation each have antecedents in FCNs and nineteenth-century commercial treaties.

International claims commissions and ad hoc tribunals dealing with the property of foreigners are a type of 'second cousins' of investor-state arbitration. These commissions were characterized by an essential state-to-state mode of adjudication; ${ }^{19}$ the establishment of semi-permanent decision-making bodies with certain levels of 'independency' of their members; ${ }^{20}$ and consensual third-party adjudication, which many times involved contentious (and sometimes dramatic) events. Suffice it to say that the latter feature required intense diplomatic efforts or - quite frequently what was termed as "'gunboat diplomacy,'" a now prohibited manifestation of self-help in international affairs. ${ }^{21}$

Domestic systems also played (and still play) a fundamental role in disputes over foreign investment, in large part because at the core of such disputes tends to be the relationship of property. National authorities have original jurisdiction over this relationship. They may decide any conflicts originating as a consequence of the state's involvement in the recognition, regulation, affectation, extinction, etc., unless the state consents to an international form of dispute settlement. Internationalization was - in part-also a response to demands to complement some of

TRANSNAT'L L. 1, 5-8 (2006) (explaining the traditional diplomatic protections available to foreign investors harmed by breaches of international law).

19 See Kenneth J. Vandevelde, The Bilateral Investment Treaty Program of the United States, 21 CORNELl INT'L L.J. 201, 265 (1988) (describing the 1983 draft's state-to-state dispute provisions); see also ROBERT RENBERT WILSON, UNITED STATES COMMERCIAL TREATIES AND INTERNATIONAL LAW 104, 104-12 (1960) (discussing property protections in pre-1923 commercial treaties).

20 According to Professors Eric Posner and John Yoo, judges are "independent" when they are appointed in advance of any particular dispute and serve fixed terms. Eric A. Posner \& John C. Yoo, Judicial Independence in International Tribunals, 93 CALIF. L. REV. 1, 12 (2005).

21 Thomas H. Lee, The Safe-Conduct Theory of the Alien Tort Statute, 106 Colum. L. REV. 830, 880 (2006) ("[U]nder traditional state-based principles of international law -i.e., those from the late eighteenth to the early twentieth centuries - the safeconduct promise was enforceable through the offended sovereign's right to make war in the event of a breach."). See SiR James Cable, Gunboat Diplomacy 19191979: POLITICAL ApPlications OF LiMited NAVAL FORCE 39 (1981) ("Gunboat diplomacy is the use or threat of limited naval force, otherwise than as an act of war, in order to secure advantage, or to avert loss, either in the furtherance of an international dispute or else against foreign nationals within the territory or the jurisdiction of their own state."). 
the perceived deficiencies of domestic courts and in some cases the inexistence of competent justice systems. ${ }^{22}$ Especially in the eyes of capital exporter countries, national courts-particularly in the recently de-colonialized world-raised concerns as to capacity for speedy, neutral, and technical resolution of claims. ${ }^{23}$ That was a convenient framing too since, perhaps, they were worried of rollbacks of concessions and nationalizations.

Thus, in theory, prior to the expansion of investor-state arbitration, the cases involving property of aliens abroad were initially treated as domestic conflicts, unless the parties had agreed on compulsory arbitration. Only after spending economic, diplomatic, or military resources could international adjudication follow in a mercantilist (state-to-state) mode. Only states could bring claims following the formal rules derived from general international law, commonly known as exhaustion of local remedies, espousal of claims, and diplomatic protection. ${ }^{24}$ Dr. Aron Broches, often referred to as the founding father of ICSID, explains the fundamental change brought by the Convention in the following way:

\footnotetext{
22 Adjudication was rarely the result of pre-established dispute settlement arrangements, and very often the result of international agreements or compromises entered into by states after the alleged illicit conduct. More than once, those agreements to adjudicate disputes that affected the economic interests of nationals abroad were the product of forcefully negotiated concessions or settlement or peace agreements. See Luis M. Drago, State Loans in Their Relation to International Policy, 1 AM. J. INT'L L. 692, 692 (1907) (describing the "steps taken by England, Germany and Italy in . . 1902, against Venezuela for the settlement of claims of various sorts"). But see generally MICHAEL TOMZ, REPUTATION AND InTERnAtional CoOperation: SOVEREIGN DebT ACross Three CENTURIES (2007) (arguing that the use of force to collect Venezuelan debt was exceptional and not motivated solely by default).

23 Christoph H. Schreuer, The ICSID CONVEnTION: A COMMEnTARY 6 (2001) ("Rightly or wrongly, the national courts of one of the disputing parties are not perceived as sufficiently impartial.").

24 Some argue that the exhaustion of local remedies is also a substantive obligation. See Andrea K. Bjorklund, Waiver and the Exhaustion of Local Remedies Rule in NAFTA Jurisprudence, in NAFTA INVESTMENT LAW AND ARBITRATION: PAST Issues, CurRent Practice, Future Prospects 253, 259 (Todd Weiler ed., 2004) ("The proceduralists have won the debate. It is clear that acts outside denials of justice can form the basis for international claims and that state parties can waive the requirement of exhaustion of local remedies. Moreover, in the investment treaty context that fact is explicit-most treaties set forth a list of potential violations, such as a failure to provide national treatment or an expropriation not in accordance with international law.")
} 
From the legal point of view, the most striking feature of the [ICSID] Convention is that it firmly establishes the capacity of a private individual or a corporation to proceed directly against a State in an international forum, thus contributing to the growing recognition of the individual as a subject of international law. ${ }^{25}$

In fact, the private right of action for damages enabled (and pioneered) by ICSID navigates the contours of private and public law, contractual and general rights and obligations, individual and State participation, and national and international law. It does so by borrowing elements from different legal structures, ${ }^{26}$ including public and private international law, ${ }^{27}$ international arbitration and $\mathrm{ADR},{ }^{28}$ and international relations and diplomacy. ${ }^{29}$ Some of these

25 Aron Broches, The Convention on the Settlement of Investment Disputes Between States and Nationals of Other States, in SELECTED ESSAYS: WORLD BANK, ICSID, AND OTHER SubJeCts OF PUBlic AND PRIVATE INTERNATIONAL LAW 188, 198 (1995) [hereinafter Broches, ESSAYS] (footnote omitted). The word striking, of course, was an exaggeration. Individuals had access to international tribunals prior to ICSID (e.g. Central American Court of Justice). See Manley O. Hudson, The Central American Court of Justice, 26 AM. J. INT'L L. 759, 769-770, 772-773 (1932) (describing individual access to the Central American Court of Justice).

26 The ICSID Convention came into force in October 1966. The rules and regulations were modeled on different sources. See Antonio R. Parra, The Development of the Regulations and Rules of the International Centre for Settlement of Investment Disputes, 22 ICSID REV.-FOREIGN INVESTMENT L.J. 55, $55-57$ (2007) (describing the creation of ICSID, and its rules and regulations and noting that the rules "also drew inspiration from, among other sources, the Statute and Rules of the World Court, the International Law Commission's 1958 Model Rules on Arbitral Procedure and the Permanent Court of Arbitration's 1962 Rules for Arbitration and Conciliation for Settlement of International Disputes Between Two Parties of Which Only One is a State").

27 The system borrows important legal infrastructure from international law. Irrespective of whether or not an international investment agreement ("IIA"), contract, or investment law refers to international law as the law applicable to the merits of the dispute, international law will be the law governing the dispute to the extent that what is at stake is the international responsibility of a state. The tools available under public international law for the interpretation and the application of a treaty also determine formal elements of jurisdiction, competence, attribution, and reparation. See Yas Banifatemi, The Law Applicable in Investment Treaty Arbitration, in ARBITRATION UNDER INTERNATIONAL INVESTMENT AGREEMENTS: A Guide To The Key Issues 191 (Katia Yannaca-Small ed., 2010) (explaining the choice of law process in international arbitration).

28 Investor-state arbitration borrows from international arbitration and ADR the idea of technical specialization to deal with matters wherein the technical complexity surpasses the knowledge of generalist or parochial judges. It also borrows the idea of procedural fairness and territorial 'neutrality' reflected in institutions such as the party appointed arbitrator/conciliator and, in the case of 
fundamental characteristics were outlined at the outset of the negotiations of the ICSID Convention as follows:

a recognition by [s]tates of the possibility of direct access by private individuals and corporations to an international tribunal in the field of financial and economic disputes with Governments;

a recognition by [s]tates that agreements made by them with private individuals and corporations to submit such disputes to arbitration are binding international undertakings;

the provision of international machinery for the conduct of arbitration, including the availability of arbitrators, methods for their selection and rules for the conduct of the arbitral proceeding;

provision for conciliation as an alternative to arbitration. ${ }^{30}$

This brief background is useful to launch the three most common justifications used to defend investor-state arbitration. When dissected, the three sources support different

the ICSID system, delocalized arbitration to ensure the recognition, enforcement, and execution of the arbitration even against the losing party's will. See Parra, supra note 26, at 60 (describing how Rule 6(2) was changed because arbitrators were increasingly required to disclose any past interaction or relationship with parties); W. Michael Reisman, International Investment Arbitration and ADR: Married but Best Living Apart, 24 ICSID REV.-FoREIGN INVESTMENT L.J. 185, 185-92 (2009) (arguing that ADR and international arbitration are both "adversarial" to each other and supplement each other, and often are pushed to come to settlements by the threat of compulsory arbitration).

29 Reputation and the preference for negotiated outcomes are important elements of international relations practice. Under the eyes of the planner, in an internationally interdependent world, a trustworthy reputation is necessary to attract FDI. Reputation and cooperation are important for assessing trustworthiness of international actors and increase the likelihood that they will abide by the terms of negotiated agreements. These features are evident in clear mandates for registration to assess formal elements of jurisdiction and ripeness of claims. See Aron Broches, Theory and Practice of Treaty Registration with Particular Reference to Agreements of the International Bank (1957), in Broches, EsSAYS, supra note 25 , at 99, 129-58 (examining the attitude of the ICJ and its failure to address treaty non-registration by reviewing five cases where the issue of registration should have been raised but was ignored).

30 A. Broches, Gen. Couns., Note Transmitted to the Executive Directors: Settlement of Disputes betWEen Government AND PRivate Parties (1961), reprinted in INT'L CTR. FOR SETTLEMENT OF INVESTMENT DisP., 2 THE HistORY OF THE SID CONVENTION: PART 1 at 1, 2 (1968) [hereinafter BROCHES NOTE]. 
understandings of what the primary function of the remedy is, emphasize a different theory of compensation promoted by the remedy, and sustain different views of the relationship between the remedy enabled and the nature of rights conferred under the international investment instruments.

\subsection{Procedural Justice: Guarantee of Bargaining Power}

The particular dynamics found in asymmetric conflicts over property relationships involving states and foreign investors have served as the main justification for investor-state arbitration. Under this view, the remedy represents a response to calls for access to effective justice in the form of readily available, competent, neutral, and procedurally informal (compared to the formalities imposed by public international law) processes for resolving disputes involving investments abroad. 31 Ideologically, it reflects the response to a particular way of problematizing a type of economic conflicts and the variability (and specificity) of factors involved. ${ }^{32}$ In response to these demands, investor-state arbitration institutionalizes a form-perhaps the preferred method - of international investment disputes settlement. ${ }^{33}$

Under this justification, the invocation of responsibility by a non-state actor against a host state is designed primarily to respond to concerns over procedural justice. Chiefly, the remedy is designed to grant direct access to seek a settlement or award that confirms that a disrupted investment by the hands of the state had value. ${ }^{34}$ Arbitration, the dispute settlement technique and framework of dialogue, is consensual, and attempts to encourage negotiated outcomes (i.e., amicable settlement between the

31 See Edwin M. Borchard, The Diplomatic Protection of Citizens Abroad 29 (1915) (" $[\mathrm{I}] \mathrm{t}$ is clear that by international law there is no legal duty incumbent upon the state to extend diplomatic protection. Whether such a duty exists toward the citizen is a matter of municipal law of his own country, the general rule being that even under municipal law the state is under no legal duty to extend diplomatic protection.").

32 See generally William L.F. Felstiner et al., The Emergence and Transformation of Disputes: Naming, Blaming, Claiming . . ., 15 LAW \& SOC'Y REV. 631 (1981) (arguing that disputes in general are social constructs).

33 See, e.g., id.; Jan Paulsson, Arbitration without Privity, 10 ICSID REV.-FOREIGN INVESTMENT L.J. 232, 232 (1995) ("This new world of international arbitration is one in which the claimant need not have a contractual relationship with the defendant.")

34 See generally E. Allan Lind et al., Individual and Corporate Dispute Resolution: Using Procedural Fairness as a Decision Heuristic, 38 ADMIN. SCI. Q. 224, 225 (1993). 
parties). ${ }^{35}$ The procedural rules establish a basic methodology that ensures that a party cannot block the proceedings by refusing to cooperate in the tribunal constitution ${ }^{36}$ and ensures a basic formal equality during the process of adjudication. ${ }^{37}$

Under this first claim, the threat of 'neutral' international dispute settlement means that even the sturdiest state can become attractive for investors, including states who had not originally stipulated international forms of dispute settlement in individual contracts. This feature, also known as open-ended consent to arbitration, obviates the need for investors to negotiate the internationalization of a regime consisting of arbitration and an international law clause into individual contracts with the host state.

Professor Michael Reisman presents the concept of investorstate arbitration as primarily a remedy to facilitate negotiated outcomes and guarantee bargaining power in a fundamentally asymmetrical context as follows:

A common feature of foreign direct investment is that the investor has sunk substantial capital in the host [s]tate, and cannot withdraw it or simply suspend delivery and write off a small loss as might a trader in a long-term trading relationship. The Romans said "potior est conditio defendentis," and this is likely to be the situation in foreign direct investment. So rather than having an equality of bargaining power in an exclusively negotiation-based regime, parity will cease and things will tilt heavily in favor of the respondent [s]tate. Unless, that is, both sides appreciate that if negotiations fail, compulsory arbitration will follow. ${ }^{38}$

35 See generally Convention on the Settlement of Investment Disputes Between States and Nationals of Other States (ICSID), Rules of Procedure for Arbitration Proceedings, r. 21, available at http://icsid.worldbank.org/ICSID/ICSID/ RulesMain.jsp (governing pre-hearing conference) [hereinafter ICSID Arbitration Rules].

36 See ICSID Convention, supra note 11, at art. 38 (allowing Chairman to appoint an arbitrator ninety days after notice at the request of one party, and after "consulting both parties as far as possible"). See also ICSID Arbitration Rules, supra note 35, at r. 4 (governing appointment of arbitrators by the chairman of the administrative council).

37 See, e.g., ICSID Arbitration Rules, supra note 35, at r. 19-28.

38 Reisman, supra note 28, at 190-91. 


\subsection{Corrective Justice: Compartmentalization of International Economic Conflicts}

The second justificatory source, corrective justice, adopts the stereotype followed by some international law experts that power is a force that works in opposition to law. Prior to the expansion of investor-state arbitration, international conflicts over the treatment of foreign property experienced the direct involvement of the states of nationality of the investor and the investment's host. In such context-according to the second foundational idea underpinning the remedy-the involvement would inescapably favor powerful states over weaker ones. With the increasing complexity of international relations, this could give rise to paralyzing diplomatic confrontations and destructive zero-sum games between states affected by the conflict. 39

Investor-State arbitration, however, attempts to create a mutually beneficial setting for several of the parties involved. It does so by compartmentalizing potentially daunting conflicts between states into individual disputes between investors and states. This-some may argue-helps to "de-politicize" internationally distressing conflicts, liberating a tense space between states to be employed for building constructive relationships. ${ }^{40}$ This approach assumes that law tames the role of power in world politics, favoring long-term cooperation, stability and diplomatic solidarity.

As the goal-based argument goes, to compartmentalize conflicts and relax state-to-state relations, a less formal order (as compared to the system of adjudication of public international law) and, to some extent, more transparent process (as compared to the informal efforts that the WB would provide at request of member states) was "institutionalized." 41 Thus, by allowing an individual

39 Cf. Richard H. Steinberg \& Jonathan M. Zasloff, Power and International Law, 100 AM. J.INT'L L. 64, 65 (2006) (“[L] egal rules and institutions did not arise out of the power of the coercive state but, rather, out of custom, consensus, and private ordering.")

40 See Martins Paparinskis, The Limits of Depoliticisation in Contemporary Investor-State Arbitration, in 3 SELECT PROCEEDINGS OF THE EUROPEAN SOCIETY OF INTERNATIONAL LAW 271, 273 (James Crawford \& Sarah Nouwen eds., 2012) (arguing that the concept of de-politicization may be used in four different fashions but "has no self-evident use for conceptualising and resolving modern challenges"). In this article, I take the meaning officially advanced by ICSID's leadership and not other possible uses of the same concept.

41 BROCHES NOTE, supra note 30, at 6. 
or a corporation to proceed directly against a state in an international forum, the remedy should help to reduce the interference of the state of nationality of the investor in the domestic affairs of the host state. This should also be reassuring for the host state because it allows it to avoid the acceptance of the jurisdiction of the courts of another, often more powerful, state. ${ }^{42}$

With a remedy to directly enforce breaches of international investment law, the foreign investor improves her position by having a better ability to assess the risks in investing abroad, and, if the reasonable operating assumptions are affected by excessive government intervention, the foreign investor may be able to succeed and obtain reparation in an independent legal process. ${ }^{43}$ By obviating the need for diplomatic protection, the investor has much more control, including the ability to influence the outcome by bringing arguments that better fit her reality and appointing neutral arbitrators. The investor is also insulated from the arbitrariness of the practice of diplomatic protection. In this sense, under this second functional source, investor-state arbitration follows a corrective justice rationale because it is more interested in the "victim's" perspective, i.e., the entity that allegedly suffered injustice at the hands of the infracting state. ${ }^{44}$

For the host state and the state of nationality of the investor the benefits are also clear: not only can the respondent avoid-in theory-facing the state of nationality of the investor (often more powerful given investment trends) in the dispute, but both could focus on building constructive relationships and avoiding foul claims over money. ${ }^{45}$ This individual-state mode of dispute

42 Id.

43 See Philip C. Jessup, Responsibility of States for Injuries to Individuals, 46 COLUM. L. REV. 903, 908 (1946) (describing the pre-ICSID limitations on foreign investor's power). See also J.L. BRIERLY, THE LAW OF NATIONS: AN INTRODUCTION TO THE INTERNATIONAL LAW OF PEACE 277-78 (6th ed., 1963) (arguing that state-tostate procedure "is far from satisfactory from the individual's point of view. He has no remedy of his own, and the state to which he belongs may be unwilling to take up his case for reasons which have nothing to do with its merits").

44 See George P. Fletcher, Remembering Gary-And Tort Theory, 50 UCLA L. REV. 279, 287 (2002) (discussing the history of modern corrective justice theory, and arguing that "strict liability-liability for harmed caused by risk-taking without wrongdoing - is a fact of modern tort law").

45 See Hersch Lauterpacht, The Subjects of the Law of Nations, 63 L. Q. REV. 438, 454 (1947), reprinted in 2 INTERNATIONAL LAW, BEING THE COLLECTED PAPERS OF HERSCH LAUTERPACHT 487, 504 (Elihu Lauterpacht ed., 1975) (arguing that the espousal of a claim by the state tends to impart the complexion of political controversy and of unfriendly action); see also ICSID Convention, supra note 11, at 
settlement will reduce the possibility of abuses by powerful states by prohibiting the espousal of the claim unless, of course, the respondent state fails to abide by and comply with the pecuniary obligations of the awards. ${ }^{46}$ This goal of de-politicization also requires building a specific legal and institutional infrastructure. This infrastructure represented a historical quid pro quo: the private right of action and the commitment of states to recognize and enforce pecuniary obligations as if they were the final judgment of a national court were paralleled by the obligation on the part of the state of nationality of the investor to exercise restraint and not to intervene in the dispute. ${ }^{47}$

In short, this second defense of investor-state arbitration originates from the attempts to compartmentalize international economic conflicts and the consequent insulation of inter-state politics through a formal international legal process. ${ }^{48}$ Under this view, the remedy is chiefly a system of protection for foreign

art. 27 ("No Contracting State shall give diplomatic protection, or bring an international claim, in respect of a dispute which one if its nationals and another Contracting State shall have consented to submit or shall have submitted to arbitration under this Convention, unless such other Contracting State shall have failed to abide by and comply with the award rendered in such dispute.").

46 See SCHREUER, supra note 23, at 416 ("[T] he arbitration procedure provided by ICSID offers considerable advantages to both sides. The foreign investor no longer depends on the uncertainties of diplomatic protection but obtains direct access to an international remedy. The dispute settlement process is depoliticized and subjected to objective legal criteria .... In turn, by consenting to ICSID arbitration the host State obtains the assurance that it will not be exposed to an international claim by the investor's home State, as long as it abides by the award.")

47 ICSID Convention, supra note 11, at art. 54 (capturing the particular advantage of ICSID, since its methodology also allows for what is called a delocalized system of enforcement preventing the intervention of domestic courts in reviewing ICSID decisions). See also Edward Baldwin, Mark Kantor \& Michael Nolan, Limits to Enforcement of ICSID Awards, 23 J. INT'L ARB. 1, 1 (2006) (quoting Mar. Int'l Nominees Establishment (MINE) v. Republic of Guinea, ICSID Case No. ARB/84/4, Ad Hoc Committee Decision of December 22, 1989, 5 ICSID REV. FILJ 95 (1990)) (stating that the ICSID Convention "excludes any attack on the award in the national courts").

48 See generally Ibrahim F. I. Shihata, Toward a Greater Depoliticization of Investment Disputes: The Role of ICSID and MIGA, in INVESTING WITH CONFIDENCE: Understanding Political Risk Management in the 21st Century 2 (Kevin W. Lu, Gero Verheyen \& Srilal M. Perera eds., 2009); see also Robert B. Shanks, Lessons in the Management of Political Risk: Infrastructure Projects (A Legal Perspective), in Managing InTERnational Political Risk 85, 93 (Theodore H. Moran ed., 1998) ("The politically sensitive nature of infrastructure projects [and] their relative vulnerability to government interference ... heightens the importance of . . dispute resolution procedure."). 
investors and de-politicization of investment disputes. This view of investor-state arbitration was adopted by Ibrahim Shihata. The former Secretary-General argued that the remedy enabled by the ICSID Convention "provide[s] developing countries with a response which, compared to the Calvo Doctrine, is both more adequate in the depoliticization of disputes and more effective in the encouragement of foreign investment, without inviting the abuses of diplomatic protection." 49

\subsection{Deterrence: Prevention of Opportunistic Behavior of States}

The post-War stabilization efforts resulted in the continued desire on the part of western policy-makers to involve private enterprise in economic activity and to encourage private investment to eventually replace aid programs and state subsidization. At the same time, these efforts contributed to understanding risk management and the creation of agencies to address non-commercial risks like inconvertibility, expropriation, civil war, revolution, or insurrection. ${ }^{50}$

These ideas of risk reduction, free market, and economic efficiency underscore the third functional goal of investor-state arbitration: prevention of opportunistic behavior of states. Informed by 'neoclassical' economic theory, some economists and development specialists advocated-successfully-for the extension of a private right of action for damages as a risk reducing commitment. Under this theory, private FDI leads to economic growth and economic development. In order to encourage FDI, well-defined property rights adopted in different instruments of protection (i.e., relationship-specific contracts, foreign investment laws, or investment treaties) shall be complemented by access to a functional dispute-settlement forum. Without a proper forum,

49 Shihata, supra note 48, at 23. See also Andreas F. Lowenfeld, The ICSID Convention: Origins and Transformation, 38 GA. J. INT'L \& COMP. L. 47, 54 (2009) (noting the some countries' opposition to the ICSID Convention because "it implied curtailment of the judicial branch's monopoly of the administration of justice, and would grant foreign investors a legally privileged position").

50 See SHAYERAH Illas AKHTAR, CONG. RESEARCH SERV., 7-5700, The Overseas PRIVATE INVESTMENT CORPORATION: BACKGROUND AND LEGISLATIVE ISSUES 2-3 (2013), available at www.fas.org/sgp/crs/misc/98-567.pdf (stating that Overseas Private Investment Corporation ("OPIC") insures investments against currency inconvertibility, expropriation, and political violence). 
property rights' enforcement would be unreliable, and unreliability creates higher risks as well as lower incentives to invest. 51

Under this third justificatory source, investor-state arbitration is first a mechanism for enforcement of international commitments that would deter opportunistic and rapacious behavior or capture on the part of governments against foreign investors. The remedy is therefore considered to be the enforcement side that minimizes some risks for long-term commitment of resources. The quid pro $q u o$ in this strategy requires states to surrender original jurisdiction for potential claims to international investment dispute settlement in the hope of attracting sustained fluxes of FDI that will increase the possibilities for economic development. For that, the theoretical focus of the remedy is deterrence; the process of economic compensation to affected investors serves mainly as an ex post remedy in order to assure that ex ante potential wrongdoers will weigh the costs of injury against the benefits of productive activity.

Under this third claim, investor-state arbitration enables the use of private rights of action for damages as a risk-reducing commitment. The argument follows that this deters the opportunistic behavior of states, having in mind-in the long run-incentivizing foreign investment. This theory is expressed in the analysis of law and economic scholars like Professor Alan O. Sykes:

[T] he utility of a private right of action for money damages is obvious. To see why, consider a world of BITs without the private action. In the event of an uncompensated expropriation or similar action, an investor would have to lobby [her] own government to take some sort of action against the violator state. The investor might be politically inefficacious in this process for any number of reasons. [She] might be unable to offer enough political benefits in return for the governments' assistance. [Her] government might have diplomatic reasons for declining to take any action or for declining to retaliate against the violator in any effective way. And even if some retaliation were forthcoming, the retaliation might do nothing to

51 See BROCHES Note, supra note 30, at 244 (quoting one of the delegates participating in the ICSID Convention negotiation, "economic development could not be achieved without capital and ... developing countries would not obtain capital unless they provided adequate [legal] guarantees"). 
compensate the investor for [her] losses. Considerable risk for investors would remain, and the risk premium on new investments would reflect it. A credible promise of monetary compensation to investors, by contrast, in an amount set by neutral arbitrators, goes much further to reduce investment risk and to achieve the developing countries' goal of lowering the cost of foreign capital. ${ }^{52}$

In summary, functionally investor-state arbitration can be conceptualized in three different ways: first, as a method for investment dispute settlement; second, as a system to achieve legalization towards an increased 'de-politicization' of investment disputes; and, third, as a mechanism for the removal of impediments to the free international flow of private investment that are posed by non-commercial risks. This distinction also reaffirms the three dimensions of investor-state arbitration and stresses particular theories of compensation: first, as the preferred specialized international method for investment dispute settlement concerned with procedural justice; second, as a (self-contained and delocalized in the case of ICSID) process to deciding legal disputes between states and investors allowing for direct corrective justice; and third, as a multilateral enforcement mechanism concerned with deterrence of conducts affecting investments abroad. Of course, these three distinctions are somehow oversimplified, but I believe they capture the basic intuitions that may animate the arbitrators' reasoning. The following section discusses how each of these different conceptions may animate a different functional relationship with treaty rights under international law.

\section{NATURE OF RigHT: FUNCTIONAL RELATIONSHIP}

In this section, I use the debate around the operation of a countermeasure in response to an anterior breach by a home state in the investor-state context to show how the three approaches may imply different functional relationships with the rights conferred under BITs.

52 Alan O. Sykes, Public Versus Private Enforcement of International Economic Law: Standing and Remedy, 34 J. LEGAL STUD. 631, 643 (2005). 


\subsection{Background}

The debate arose in the context of the North American Free Trade Agreement (NAFTA) investment provisions. ${ }^{53}$ After a longstanding disagreement regarding the specific meaning of the treaty provisions, the Mexican Congress approved a controversial excise tax on the use of fructose on soft drinks. Instead of collecting revenue, the tax indirectly forced soft drink producers to use Mexican sugar by excessively taxing the sale of soft drinks made with fructose while exempting those made with cane sugar. The measure openly discriminated against fructose producers in Mexico (almost exclusively owned by U.S. investors).

Four U.S. companies started three investor-state arbitration proceedings on behalf of their controlled and locally-incorporated subsidiaries. Since Mexico's efforts to consolidate these claims failed, the cases were conducted in separate proceedings. The claimants argued that the tax was, among other things, inconsistent with Mexico's national treatment obligation under the investment protection provisions of NAFTA.

During the investor-State proceedings adjudicating these claims, Mexico conceded the discriminatory character of the tax but argued that it was a "legitimate countermeasure" that precluded wrongfulness adopted in response to what Mexico characterized as a prior U.S. violation of intra-state obligations under NAFTA. The three tribunals decided that the tax was discriminatory, in violation of the national treatment obligation, and that Mexico's actions entailed liability. However, the tribunals faced the question of whether a countermeasure for the alleged prior violations by the United States could be directly applicable to investors. While reaching the same practical outcomes, the three tribunals decided the case differently, sparking a doctrinal debate regarding the nature of investors' rights. ${ }^{54}$

Such controversy has been elegantly dissected by Martins Paparinskis as follows:

53 See generally North American Free Trade Agreement, U.S.-Can.-Mex., Dec. 17, 1992, 32 I.L.M. 289 (1993) [hereinafter NAFTA].

54 See Joost Pauwelyn, Adding Sweeteners to Softwood Lumber: The WTONAFTA 'Spaghetti Bowl' is Cooking, 9 J. INT'L ECON. L., 197, 197-200 (2006) (discussing the complexity of parallel proceedings within different international frameworks, which can sometimes yield inconsistencies). 
[e]ven though the host state may in principle apply countermeasures to investment obligations, their effect and limits depend on the nature of the investors' rights. Countermeasures are relative in effect and may not be adopted otherwise than in response to a prior breach of international law by the entity to which the obligation is owed. 55

In his brilliant contribution addressing this topic, he explains that adopting the analytical perspective of investors' rights either as right-holders (by reference to human and consular rights analogies), beneficiaries (by reference to the law of treaties rules on third states analogies), or agents (by reference to diplomatic protection analogies), has the following implications:

From the perspective of delegated diplomatic protection, the host state owes primary obligations only to the home state, and the investor only invokes responsibility for their breach; consequently, countermeasures can be successfully opposed to the only beneficiary of the obligation and can in principle successfully preclude wrongfulness, provided that other criteria are satisfied. However, if the investor is also the beneficiary of the obligation (whether akin to a third party or as an entity with direct rights), then the precluding wrongfulness of countermeasures, while opposable to one beneficiary (the home state), is not opposable to the other beneficiary (the investor). ${ }^{56}$

\subsection{Third-Party Rights: Access to Justice and Dispute Settlement}

As presented under the procedural justice approach, investorstate arbitration serves fundamentally as a remedy to ensure access to justice, neutrality, and fairness by empowering individuals and corporations to directly participate in a dispute settlement process - arguably an option that may be unavailable to foreigners before domestic justice systems or elsewhere. Without fully

55 Paparinskis, supra note 2, at 632 (emphasis added).

56 Id. Cf. Anthea Roberts, State-to-State Investment Treaty Arbitration: A Hybrid Theory of Interdependent Rights and Shared Interpretive Authority, 55 HARV. INT'L ECON. L. J., 1, 68-70 (2014) (concluding "that investment treaty rights are granted to investors and home states on an interdependent basis, and interpretive authority is shared between the treaty parties, investor-state tribunals, and stateto-state tribunals.") 
entering into the merits of such debate, it is fair to say that the defense of investor-state arbitration under this basis can be taken with a grain of salt. For instance, it is often argued that investorstate arbitration is not fair because decision-makers are not truly independent. ${ }^{57}$ According to some authors, "the development of this new 'common law of investment' has been placed primarily in the hands of an exceedingly small pool of super-elite, like-minded international lawyers who operate largely divorced from any municipal political process." 58 Moreover, in part because of design elements (e.g., cost, capacity, access to expertise, etc.), investor-state arbitration is not truly accessible to the majority of the business community. ${ }^{59}$ Therefore, the investor-state may only serve the interests of large transnational corporations since in actuality the remedy is accessible to very few actors, and arguably only supports already empowered global economic participants.

In any event, the direct invocation of responsibility by a nonstate actor against a host state in an arbitral setting under this perspective serves a fundamental task: to provide foreigners investing abroad with a neutral, non-state forum for reparation that may increase access to justice and by implication equalize bargaining power between the sovereign and the regulated party.

The majority decision of the tribunal in Corn Products v. Mexico (Greenwood and Serrano de la Vega) may be paradigmatic of the impulse to think of investor-state arbitration as a remedy

57 See Emilie M. Hafner-Burton et al., Political Science Research on International Law: The State of the Field, 106 AM. J. INT'L L. 47, 85 (2012) ("Political scientists have recently analyzed several ways in which delegation of problems and conflicts to international courts shapes legal evolution. One important finding is that the extent of such delegation increases with two variables relating to the design of courts: judicial independence (which depends on the selection method and tenure of judges) and access. Another important finding-which resonates with work done by lawyers on the impact of independent tribunals - is that access for private, non-state litigants and compulsory jurisdiction both contribute to judicial independence.") (footnotes omitted). See generally PIA EBERHARDT \& CECILIA Olivet, Corp. Eur. Observatory \& Transnat'L InSt., Profiting From Injustice: HOW LAW Firms, ARbitrators and FinANCIERS ARE FuElling aN INVESTMENT ARBITRATION BOOM (2012), available at http://corporateeurope.org/trade/ 2012/11/profiting-injustice.

58 Jason Webb Yackee, Pacta Sunt Servanda and State Promises to Foreign Investors Before Bilateral Investment Treaties: Myth and Reality, 32 ForDHAM INT'L L.J. 1550, 1611 (2009).

59 See Karen J. Alter, Private Litigants and the New International Courts, 39 COMP. POL. STUD. 22, 46 (2006) (noting that notwithstanding the increase of compulsory jurisdiction, international adjudicative bodies still have limited resources for the majority of the business community). 
fundamentally concerned with access to justice and dispute settlement. Functionally, the remedy formalizes a procedure that ensures a certain level of neutrality for addressing conflicts. It gives the affected investors direct control over the claims, and ensures that proceedings can continue even without direct participation of the host state. The following excerpt of Corn Products compares the investors' own benefit of international obligations to the rights of a third party, and hence the remedy is a procedural endeavor primarily concerned with access to international justice:

It has long been the case that international lawyers have treated as a fiction the notion that in diplomatic protection cases the State was asserting a right of its own-violated because an injury done to its national was in fact an injury to the State itself. It was a necessary fiction, because procedurally only a State could bring an international claim, but the fact that it did not reflect substantive reality showed through not only in the juristic writing but also in various rules of law surrounding diplomatic protection claims . . . . However, there is no need to continue that fiction in a case in which the individual is vested with the right to bring claims of its own. In such a case there is no question of the investor claiming on behalf of the State. The State of nationality of the Claimant does not control the conduct of the case. No compensation which [sic] is recovered will be paid to the State. The individual may even advance a claim of which the State disapproves or base its case upon a proposition of law with which the State disagrees .... [Hence] an investor which brings a claim is seeking to enforce what it asserts are its own rights under the treaty and not exercising a power to enforce rights which are actually those of the State ... . [T] his is a case involving the rights of a third party and not merely its interests. Mexico owed obligations ... separate from the obligations it owed to the United States . . . [hence] countermeasures could operate to preclude the wrongfulness of the HFCS tax vis-à-vis the United States [but not vis-à-vis the investor]. ${ }^{60}$

60 Corn Products. Int'l, Inc. v. The United Mexican States, ICSID Case No. ARB(AF)/04/01 (NAFTA), Decision on Responsibility, I $170-76$ (Jan. 15, 2008), 


\subsection{Direct Rights: De-Politicization and Compensation}

The specialization and de-politicization functions of the remedy are both concerned with its effects on conflict resolution. However, the de-politicization function is specifically concerned with the diplomatic relationship between the investor's state of nationality of the investor and the host state of the investor. Under this functional claim of the remedy, formalizing disputes without the involvement of the investor's state of nationality results in equality among states, limiting arbitrariness and "abuses of diplomatic protection." 61 The assumption is that without investorstate arbitration, foreign investment disputes will be relegated to the sphere of power politics, and dominant global powers would reign.62 Hence the arbitration format (investors-state) and relief (damages only) help to frame political and economic conflicts in stable ways for the pursuit of larger policy goals. ${ }^{63}$

Of course, the arbitration process cannot always guarantee fairness. International realists, as well as critical legal scholars, have long pointed to the ways in which international law itself is instrumental to and shaped by power. ${ }^{64}$ This idea may reinforce

available at

https:/ /icsid.worldbank.org/ICSID/FrontServlet?requestType=CasesRH\&action $\mathrm{Val}=$ showDoc\&docId=DC1012_En\&caseId=C29.

61 See Shihata, supra note 48, at 2, 23 (noting that in the past century abuse of diplomatic protection drove many countries to require all disputes be resolved exclusively in domestic courts, and that arbitration offers a solution because "[r]esort to ICSID precludes the investor's state from exercising diplomatic protection or instituting an international claim unless the host state fails to comply with the award rendered in such dispute").

62 See M. SORNARAJAH, The InTERnATIONAl LAW ON Foreign InVESTMENT 207 (2d ed. 2004) (stating that one feature of the IIAs "is that they are made between unequal partners," which demonstrates this dichotomy in the context of ICSID and IIA since it relates to the relationship between strong, capital-exporter states that may use power diplomacy to force weaker, capital-importer states to settle in unequal terms) (citation omitted). See also ICSID DATABASE OF BILATERAL INVESTMENT TREATIES, https://icsid.worldbank.org/ICSID/FrontServlet (last visited Apr. 3, 2014) (follow "Bilateral Investment Treaties" hyperlink) (presenting an organized database of BITs listed by country).

63 See Christian Reus-Smit, The Politics of International Law, in THE POLITICs OF INTERNATIONAL LAW 36, 36 (Christian Reus-Smit ed., 2004) ("[I]nstitutions are created by political actors as structuring or ordering devices, as mechanisms for framing politics in ways that enshrine predominant notions of legitimate agency, stabilise individual and collective purposes, and facilitate the pursuit of instrumental goals.").

64 For a classic discussion on the role of power, see KENNETH N. WALTZ, THEORY Of INTERNATIONAL POLITICS (1979) (arguing that international rules are the 
the stereotype that power is a force that works in opposition to law. 65 At the same time, the remedy may serve as substitutes that allow domestic power brokers to "exit local jurisdictions with poor institutions," or to affect judicial politics around specific normative issues by extending corrective options to foreign investors. ${ }^{66}$

The correct interpretative exercise to determine whether direct invocation of the investor should be viewed as a third party or as an entity with direct rights requires a complex analysis reaching into the broader architecture of investment law. ${ }^{67}$ I leave that discussion to more able scholars. My point is simply that under a direct rights approach of the remedy, the emphasis is in the corrective nature of the remedy. This function opens the possibility of material compensation without distressing other relationships between states (or states and its nationals) by reducing the spaces for arbitrariness and abuses that come with the exercise of diplomatic protection.

In this sense, one can read the direct right to invoke responsibility as a mechanism to correct a breach to international commitments through payment of compensatory damages. It allows the 'victim' or investor who allegedly suffered the wrong at the hands of the authorities, to obtain a finding that a breach has occurred and, if it is the case, possibly receive a direct payment of damages for the violation by the host state without any involvement of the home state. This picture of investor-state arbitration, as primarily a corrective mechanism for foreign

pronouncements of powerful states and are subject to change along with fluctuations in state power). See also John J. Mearsheimer, The False Promise of International Institutions, 19 INT'L SEC. 5, 7 (1995) (arguing that international institutions cannot have independent effects on state behavior).

65 See Steinberg \& Zasloff, supra note 39, at 74 (“[S]tate behavior and associated international outcomes may appear to be shaped by international law, but because international law mirrors the interests of powerful states, international law is merely an epiphenomenon of underlying power.").

66 See Tom Ginsburg, International Substitutes for Domestic Institutions: Bilateral Investment Treaties and Governance, 25 INT'L REV. L. \& ECON. 107, 108, 122-23 (2005) (arguing that "institutions that lie at the intersection of the domestic and international spheres" can allow a dispute to escape local institutions). For a clarification of this argument, see Sergio Puig, Investor-State Tribunals and Constitutional Courts: The Mexican Sweeteners Saga, 5 Mex. L. Rev. 199, 202 (2013), available at http://ssrn.com/abstract=2042798 ("[S]upranational adjudicatory bodies may affect domestic politics by empowering and expanding remedies available to foreign investors.")

67 Martins Paparinskis, Investment Arbitration and the Law of Countermeasures, 79 BRIT. YEARBOOK INT'́ L. 264, 297-301, 304-305 (2008). 
investors, is adopted by Professor Lowenfeld in a separate opinion in the case referred to above: Corn Products v. Mexico. He takes issue with the majority opinion's characterization of investors' rights as being similar to third-party rights, and stresses the depoliticization role of the remedy in the following passage:

[T] he essential feature of investor-[s]tate arbitration, as it has developed since the ICSID Convention . . . is that controversies between foreign investors and host states are insulated from political and diplomatic relations between states. In return for agreeing to independent international arbitration, the host state is assured that the state of the investor's nationality (as defined) will not espouse the investor's claim or otherwise intervene in the controversy between an investor and a host state, for instance by denying foreign assistance or attempting to pressure the host state into some kind of settlement. Correspondingly, the state of the investor's nationality is relieved of the pressure of having its relations with the host state disturbed or distorted by a controversy between its national and the host state. ... The paradigm in investor-States disputes, ... is a dispute between the first party (nearly always the investor) as plaintiff, and the second party (nearly always the host state or state agency) as respondent. There is no third party. ${ }^{68}$

Moreover, a different tribunal in Cargill v. Mexico (Pryles, Caron, and McRae) analyzing the exact same issue also stressed the corrective function of the remedy. After examining the arguments posed by the respondent, it concluded:

[I]t is the investor that is named in the operating paragraph or 'dispositive' of the award. . . . [the granting of rights under the investment treaty] is no different from rights of individuals within many municipal legal systems. That the origin of individual rights may be found in the act of a sovereign, or in the joint act of sovereigns, does not negate the existence of the rights conferred. ... [I]t is the investor that acts upon and benefits from the obligations . . . it is the

68 Corn Products. Int'l, Inc. v. The United Mexican States, ICSID Case No. ARB(AF)/04/01 (NAFTA), Separate Opinion of Andreas F. Lowenfeld , 91 - 4 (Jan. 15, 2008), available at https://icsid.worldbank.org/ICSID/FrontServlet? requestType $=$ CasesRH\&actionVal=showDoc\&docId=DC1012_En\&caseId=C29. 
investor that institutes the claim, that calls a tribunals into existence, and that is the named party in all respects to the resulting proceedings and award. ${ }^{69}$

\subsection{Delegated Rights: Risk Assessment and Conflict Prevention}

The final archetypal function of investor-state arbitration as a remedy of international investment law is to serve as a source of certainty and to incentivize flows of FDI.70 This is anchored in the belief that "the prospect of involvement in . . . [investor-state arbitration] proceedings will work as a deterrent to the actions which give rise to the institution of proceedings". ${ }^{71}$

The embedded idea in this conceptualization-investors as rational decision makers - has been most recently challenged by the findings of behavioral economists and social psychologists, which show that human decisions are not purely rational. ${ }^{72}$ Instead, they are susceptible to systematic biases and errors, and they are greatly affected by internal processes that do not correspond to a cost-benefit analysis. ${ }^{73}$ Similarly, scholars have long argued that law-related considerations often play a surprisingly minor role in the organization and implementation of business affairs and in decisions to invest. ${ }^{74}$ Again, I leave this

\footnotetext{
69 Cargill, Inc. v. The United Mexican States, ICSID Case No. ARB(AF)/05/2, Award, ๆ 425-26 (Sep. 18, 2009), available at http:/ / www.italaw.com/.

70 See ICSID Convention, supra note 11, - 10. See also Vandevelde, supra note 19 , at 258 (describing "binding third-party arbitration of investment disputes" as a mechanism to promote fluxes of FDI).

71 Shihata, supra note 48, at 9 (emphasis added).

72 See generally Emilie M. Hafner-Burton, D. Alex Hughes \& David. G. Victor, The Behavioral Psychology of Elite Decision Making: Implications for Political Science, UCSD Sch. Int'l Relations \& Pacific Stud., Oct. 28, 2011, at 1, available at polisci2.ucsd.edu/dhughes/research/Elites.pdf.

$73 \mathrm{Id}$.

74 See Stewart Macaulay, Non-Contractual Relations in Business: A Preliminary Study, 28 AM. Soc. REV. 55, 62 (1963) ("[W]hile detailed planning and legal sanctions play a significant role in some exchanges between businesses, in many business exchanges their role is small."). See also Stewart Macaulay, An Empirical View of Contract, 1985 WIS. L. REV. 465, 467 (1985) ("Contract planning and contract law, at best, stand at the margin of important long-term continuing business relations. Business people often do not plan, exhibit great care in drafting contracts, pay much attention to those that lawyers carefully draft, or honor a legal approach to business relationships.").
} 
debate for another time and here only refer to other important works in the area. ${ }^{75}$

The interpretation of the function of the remedy as primarily an element of deterrence emphasizes its utility for business planning and ex ante conflict prevention. It stresses that by agreeing to grant a remedy states may be less likely to commit acts, which would give rise to conflict. If so, there is a credibly "enforceable" commitment. The remedy is precisely that enforcement side that acts as an (distant) element of inhibition. The potential relief is monetary damages that serve to alleviate (some) concerns over the effective application of a 'rule of law,' especially in countries with difficult institutional environments (courts or otherwise).

Under this conceptualization of the remedy, the right to invoke responsibility against the state is akin to a delegated right. This right is assigned from the original right holders (the sovereigns) to an entire universe of economic participants, as defined by the international investment instrument. The international agreements, while celebrated between states, establish a mechanism through which the parties can give up the international right to espouse the claims of a national before an international forum. The delegation serves to protect-first and foremost - the investor by reducing the additional cost of higher risks (as reflected in the risk premium on new investments). It creates more certainty in the investor's decision process by limiting potential arbitrariness in the exercise of diplomatic protection, in the application of reprisals against a state found in violation and in the allocation of the (eventual) retaliation benefits to compensate the investor for its losses. Under the view of the "delegated diplomatic protection" the host state owes primary obligations only to the home state, and the investor only invokes responsibility for their breach. The right to invoke responsibility is the only carve-out from a "robust" and optimal regime of general international law. ${ }^{76}$ Such a regime is efficient since it ensures the proportionality of measures taken

75 See generally THE BACKLASH AgAinst InVESTMENT ARBITRATION (Michael Waibel et al. eds., 2010) (trying to identify and address some of the systemic concerns, such as limitations on domestic policy space, a lack of democratic accountability, a systemic pro-investor bias, and the inability of treaties to respond to changes in economic circumstances).

76 For this position, see Francisco González de Cossío, Investment Protection Rights: Substantive or Procedural?, 26 ICSID REV. FoREIGN INV. L.J. 107 (2011). 
when a state breaches an international obligation. ${ }^{77}$ Efficiency, of course, is a variable in risk assessment.

The majority of the tribunal in the consolidated claims of $A D M$ and Tate E Lyle Ingredients Americas, Inc. v. Mexico (Cremades and Siqueiros) also analyzed whether countermeasures could be successfully opposed to the investors. The Tribunal adopted a similar view of the remedy as the one describe above:

The procedural obligation under . . . [the investment chapter of the treaty] to submit the dispute to arbitrationwhich may arise from the breach of the primary obligations of the host State addressed in Section A-is owed directly to the beneficiary of the obligation, in this case the investors, who have opted in the present case, as a secondary right holder, to commence international arbitration proceedings under Chapter Eleven. The power to bring international arbitral proceedings under Section B, makes the investor the holder of a procedural right, irrespective of whether this right may be suspended by the NAFTA Parties .... . [It] establishes rights regarding the treatment of investors, but these rights are not owed by the host State to the investors, but to the investors' home State. Therefore, the rights provided by Section A only exist at the international plane between NAFTA Parties. Investors are the objects or mere beneficiaries of those rights. Accordingly, under Chapter Eleven, the Member States have an obligation to treat investors of the other NAFTA Parties under the standards addressed in Section A, but this obligation is only owed to the state of the investor's nationality ... It therefore follows that the only individual rights investors enjoy under Chapter Eleven is the procedural right under Section B to invoke responsibility of the host State. ${ }^{78}$

In Arthur Rovine's concurring opinion in the same case (ADM et al. v. Mexico), his skepticism of the position of his co-arbitrators reflects the pragmatism often associated with practitioners of the

\footnotetext{
77 See Case Concerning the Air Service Agreement of 27 March 1946, Decision of Dec. 9, 1978, 18 REP. INT'L ARB. AwARDS 417, 445 ("Counter-measures . . . should be a wager on the wisdom, not on the weakness of the other Party.").

78 Archer Daniels Midland Co. et al. v. The United Mexican States, ICSID AF Case No. ARB(AF)/04/5, Award, ๆ 177-79 (Nov. 21, 2007).
} 
field. He raised an important point engaging with it, in my modest view, very superficially: "[W]hat difference does it make whether an investor's right to redress for a wrong committed is . . direct or derivative?"79 As it turns out, this question "is crucial in certain cases" such as consent to the commission of a wrongful act, waivers of obligations, or the application of countermeasures - the latter a fundamental issue in such dispute. ${ }^{80}$ However, Rovine also makes an emblematic point: "[a] right to a remedy is a substantive right. Legal redress for the wrong committed is a substantive right." 81

This is perhaps the main point behind this article. While the problematic character of the "public-private" distinction has long been recognized by international legal theorists, the field pays little attention to the methodological limitations of the "proceduralsubstantive" analysis. As Paparinskis argues, the different conceptualization of the right to directly invoke responsibility against a state does not relieve the tribunal of "a diligent application of traditional techniques of legal reasoning." 82 These traditional techniques and the rules of state responsibility say very little about this substantive/procedural dichotomy. The nature of investors' rights is left to the particular primary rules. ${ }^{83}$ Attributing particular content to this primary rule, i.e., the right to directly invoke responsibility, is precisely what arbitrators do when interpreting the "procedural" dimension of international investment law. In this sense, it is understandable why different arbitrators may ascribe different meaning to it based on the different functional reasons used historically to promote investorstate arbitration. Indeed, a careful analysis of the transformation of ICSID demonstrates how the argument justifying investor-state arbitration has changed and adopted different narratives, emphasizing at times its role to grant access to justice and de-

\footnotetext{
79 Archer Daniels Midland Co. et al. v. The United Mexican States, ICSID AF Case No. ARB(AF)/04/5, Concurring Opinion of Arthur W. Rovine, I 43 (Nov. 21, 2007) [hereinafter Concurring Opinion of Arthur W. Rovine].

80 Paparinskis, supra note 2, at 646.

81 Concurring Opinion of Arthur W. Rovine, supra note 79, at 47.

82 Paparinskis, supra note 2, at 646.

83 See James Crawford, ILC's Articles on Responsibility of States for Internationally Wrongful Acts: A Retrospect, 96 AM. J. INT'L L. 874, 886-88 (2002) (discussing the articles in light of the bilateral state-to-state political climate that dominated at the time of their conception).
} 
politicization or, more recently, its potential role in national economic development.

The three-level theory presented here could be applicable and helpful to understanding other areas where tribunals show disagreement on fundamental aspects of the procedural dimension of international investment law, such as the type of noncompensatory relief (e.g., injunctions, cessation, punitive damages) obtainable in investor-state arbitration. ${ }^{84}$ Of course, such questions may, in principle be determined by the investment instrument. Assuming a lack of interpretative guidance, one could understand why arbitrators contemplating deterrence as an important role of investor-state arbitration would be more willing to accept punitive damages (to raise the 'cost' of opportunistic behavior on the hands of states), or arbitrators concerned with procedural justice would more readily grant injunctions (to avoid the difficulties faced by foreigners before domestic courts), or why arbitrators concerned with corrective justice would accept to order cessations (to limit the effects of a wrong at the hands of authorities). This is just another example of the ways in which the different functions of the remedy i.e., procedural justice, corrective justice, or deterrence speak to investment rights.

\section{CONCLUSION}

Justice Holmes once observed that "[l]egal obligations that exist but cannot be enforced are ghosts that are seen in the law but that are elusive to the grasp." 85 Without investor-state arbitration, investment law obligations would be more elusive and hence the unique role of this remedy in the future of foreign investment protection. Understanding the foundations of the main enforcement mechanism of international investment law is not

84 See Jarrod Wong, The Misapprehension of Moral Damages in Investor-State Arbitration, in CONTEMPORARY ISSUES IN INTERNATIONAL ARBITRATION AND MEDIATION: THE FORDHAM PAPERS 2012 (Arthur W. Rovine ed., 2013) (stating that reparation takes one of three forms: Restitution, compensation, or satisfaction. Restitution focuses on reversing material injuries where possible; compensation remedies financially assessable injuries, whether material or moral, that are not made good by restitution; and satisfaction remedies non-financially assessable, often symbolic, injuries that represent affronts to the state). See also Symposium, Remedies and Damages in Investment Arbitration, 54 HARV. INT'L L.J. ONLINE (2013), available at http://www.harvardilj.org/2013/03/hilj-symposium-2/ (featuring Ankita Ritwik, who gave a brief overview of remedies available in public international law).

85 Ex parte The Western Maid, 257 U.S. 419, 433 (1922). 
only academically relevant, it has practical implications for arbitrators deciding concrete disputes, or lawyers advocating positions on behalf of their clients. The subtle differences between the conceptualization of investor-state as an enforcement system i.e., procedural justice, corrective justice, or deterrence, may reach deeply as illustrated by the debate over the application of valid countermeasures under international law. Of course, these representations are to some degree caricatures, but they capture basic intuitions that may animate the arbitrators' reasoning. These differences may also evidence some of the limitations of the substance-procedure dichotomy. As illustrated by this work, the construction of substantive law entails assumptions about the procedures that will apply when that substantive law is ultimately enforced. 86

86 See generally Thomas O. Main, The Procedural Foundation of Substantive Law, 87 WASH. U. L. REV. 801 (2009). 